\title{
Histochemistry and Infrared Microspectroscopy of Lignified Tissue in Young Stems of Struthanthus vulgaris Mart.
}

\author{
Gisely de Lima Oliveira ${ }^{1 \star}$, Heber dos Santos Abreu ${ }^{1}$, \\ Tatiana de Felice Elias ${ }^{1}$, Bruno Couto da Silva ${ }^{1}$, Monique de Moura Gurgel ${ }^{1}$, \\ Carlos Henrique Rocha Gonçalves ${ }^{1}$, Geraldo Luiz Gonçalves Soares ${ }^{2}$
}

${ }^{1}$ Departamento de Produtos Florestais, Universidade Federal Rural do Rio de Janeiro - UFRRJ, Seropédica/RJ, Brasil ${ }^{2}$ Departamento de Botânica, Universidade Federal do Rio Grande do Sul - UFRGS, Porto Alegre/RS, Brasil

\begin{abstract}
In this study, we aimed to determine lignified tissue in young stems of Struthanthus vulgaris Mart. by infrared microspectroscopy and histochemical methods as well as by fluorescence microscopy. Struthanthus vulgaris Mart. is a mistletoe species that belongs to the Loranthaceae family. A brief anatomical description was also carried out. The first procedure for analysis was to elaborate anatomical cross sections $(20-30 \mu \mathrm{m})$ from young stems before and after treatment with $\mathrm{NaOH} 1 \%$. This procedure was applied to release possible low molecular mass phenolic compounds. Safranin-astra blue was used to distinguish anatomical tissues while Wiesner test enabled verification of lignified pericyclic fibers. Infrared microspectroscopy analysis confirmed the presence of lignin in this region according to the following spectral signals: 1600 (shoulder), 1511, 1453, 1338 and $1244 \mathrm{~cm}^{-1}$. Analyses of the cross section of young stems under fluorescence microscopy before and after treatment with $\mathrm{NaOH} 1 \%$ allowed us to confirm the presence of low mass phenolic compounds in the region of pericyclic fibers.
\end{abstract}

Keywords: mistletoe species, fibers, lignifications.

\section{Histoquímica e Microespectroscopia no Infravermelho de Tecido Lignificado em Caule Jovem de Struthanthus vulgaris Mart.}

\section{RESUMO}

O objetivo deste estudo foi determinar tecidos lignificados em caules jovens de Struthanthus vulgaris Mart., por microspectroscopia no infravermelho, teste histoquímico e microscopia com fluorescência. Esta é uma espécie hemiparasita da família Loranthaceae. Foi também realizada uma breve descrição anatômica. O primeiro procedimento para a análise foi realizar os cortes anatômicos transversais $(20-30 \mu \mathrm{m})$ do caule jovem, sendo feita a análise antes e após tratamento com $\mathrm{NaOH}$ 1\% para liberar substâncias fenólicas de baixa massa molecular. Utilizou-se safranina azul de astra para identificar os tecidos anatômicos, enquanto o teste Wiesner permitiu verificar fibras pericíclicas lignificadas. A análise por microespectroscopia no infravermelho confirmou a presença de lignina nesta região por meio dos seguintes sinais espectrais em 1600 (ombro), 1511, 1453, 1338 e $1244 \mathrm{~cm}^{-1}$. As análises da seção transversal do caule jovem sob microscopia de fluorescência antes e após tratamento com $\mathrm{NaOH} 1 \%$ permitiram confirmar a presença de substâncias fenólicas de baixa massa molecular na região das fibras pericíclicas.

Palavras-chave: espécie hemiparasita, fibras, lignificação. 


\section{INTRODUCTION}

Lignin is a class of phenylpropanoid macromolecule deposited in the final stages of fiber and other structural element formation. This kind of compound is set on the matrix of cell wall (Boerjan et al., 2003). In wood, lignin is found in high percentage in the secondary wall of fibers, vessels and tracheids in sap and heart wood, contributing to mechanical support, rigidity and chemical and physical defense. Its composition varies according to species, organs and tissues and even between layers of the cell wall, where it can be bound to proteins, sugars, suberin and phenol molecules (Burton et al., 2010; Raven et al., 2007; Higuchi, 1980; Browning, 1967).

Lignin in wood has been vastly studied; however, few studies on parasite plants have been published. Nevertheless, these plants play an important ecological role and it has been demonstrated that their lignification process is highly sophisticated and specific for their survival (Umezawa, 2010).

The hemiparasite Struthanthus vulgaris Mart., popularly known as mistletoe, is a species of the Loranthaceae family found in tropical and subtropical regions (Harris, 1992; Tainter, 2002; Aukema, 2003). This species is dependent upon a host plant to grow, but it can still undertake its own photosynthetic process. It clings to the branches and central trunk of host plants using a specialized rooting method called haustoria. The hemiparasite roots cross the bark of host plants until they reach the xylem, from where they drain water and minerals (Tattar, 1978; Rotta, 2001; Tainter, 2002). Lignin and its position in this species tissues are still unknown. Salatino et al. (1993) reported that this plant presents high quantities of phenolic substances. Histochemical tests and utilization of infrared spectroscopy methods have been successfully applied. Research in this field has been recently described by De Micco \& Aronne (2007) and Naumann et al. (2005).

\section{MATERIAL AND METHODS}

Stem samples were collected from Struthanthus vulgaris Mart. in the campus of the Federal Rural University of Rio de Janeiro (Universidade Federal
Rural do Rio de Janeiro - UFRRJ), Rio de Janeiro state, Brazil. Histological samples from young stem parts (from $4^{\text {th }}$ to $5^{\text {th }}$ internodes) were analyzed by optical fluorescence and infrared microspectroscopy.

Cross sections $(20-30 \mu \mathrm{m})$ of young stems from Struthanthus vulgaris were previously fixed in FAA 70\% (Formaldehyde, Glacial Acetic Acid and Ethyl Alcohol 70\% (1:1:18)) for 24 hours and then stored in ethanol 50\% (Kraus \& Arduin, 1997). Sections were performed in a Ranvier microtome and clarified through the following procedures: first, the material remained in sodium hypochlorite solution $50 \%$ for five minutes and then it was washed with distilled water to remove the excess reagent. Subsequently, the sections were placed in acetic acid solution $1 \%$ to neutralize the hypochlorite effects and were washed once more, concluding the process. Histochemical tests were performed with the use of an optical microscope (Olympus BX 51) coupled with a fluorescence device and a digital imaging system (cell ${ }^{\mathrm{f}}$ imaging software).

Histochemical analysis was carried out on crosssections $(20-30 \mu \mathrm{m})$ of young stems, stained with a solution of Astra blue 2\% and safranin $0.5 \%$ diluted in water (Bukatsch, 1972). Wiesner test was also performed to detect lignified tissue in cross sections non-treated and treated with $\mathrm{NaOH} 1 \%$ solution for 1 hour (TAPPI standards - T-212 - 76 (Tappi, 1979). Non-treated and treated cross sections of stems were observed by fluorescence microscopy, using blue excitation (450-480 $\mathrm{nm}$ ) and FITC (U-MWB2) filters.

Cross sections of young stems were sectioned by a Ranvier microtome with 20-30 thickness (in natural condition). After that, they were placed between glass slides $(2 \times 4 \mathrm{~cm})$, frozen in liquid nitrogen and then lyophilized in a TERRONI - Model ENTERPRISE lyophilizer for 12 hours. Once lyophilized, the crosssections were placed on $\mathrm{KBr}$ slides and then spectra recorded in an infrared microscope coupled to a VARIAN 640-IR FT-IR spectrometer with a liquid nitrogen-cooled Mercury Cadmium Telluride detector (MCT). Samples were run by diffuse reflectance at wavenumber range of 700-4000 $\mathrm{cm}^{-1}$, spectral resolution of $4 \mathrm{~cm}^{-1}$ and 128 scan. Spectra were recorded on the following anatomical regions: parenchyma cell, phloem fiber and pith, covering an area of $5 \mu \mathrm{m}^{2}$ for each analysis. 


\section{RESULTS AND DISCUSSION}

In the cross sections, we observed uniseriate epidermis containing cells of various shapes and sizes, followed by three to seven layers of homogeneous parenchyma consisting of isodiametric cells and collenchyma. The conductive vessels are arranged in bundles interrupted by parenchymatous cells, featuring a discontinuous cylinder. The vascular bundles are provided with pericyclic fibers adjacent to the sieve elements. In the primary state of growth, one to two layers of cells were found in the primary xylem of the central cylinder. Protoxylem and metaxylem were also observed (Figure 1).

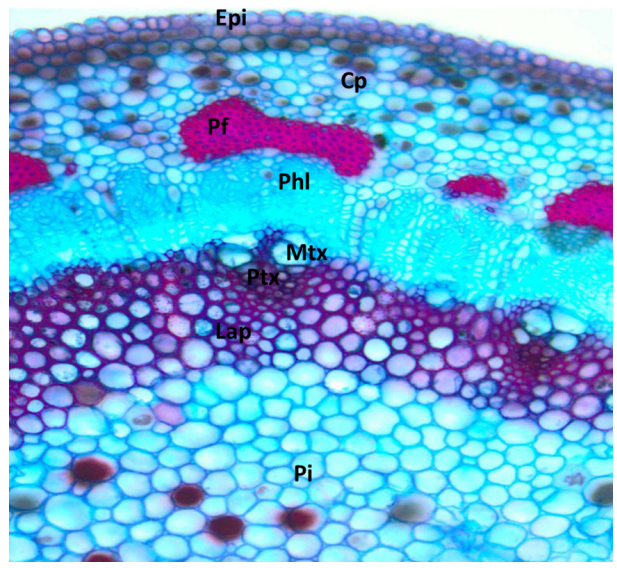

Figure 1. Cross-section of young stems of S. vulgaris stained with safranin/astra blue. Note: Epi-epidermis; cp - cortical parenchyma; pf - pericyclic fibers; phl - phloem; mtx - metaxylem; ptx - protoxylem; lap - lignified axial parenchyma; pi - pith.
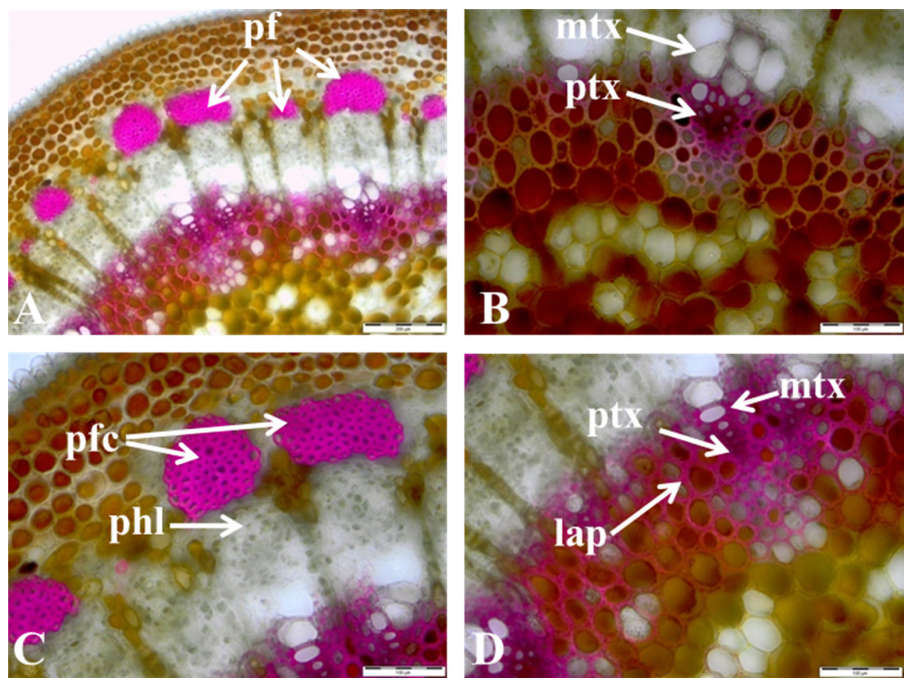

Figure 2. Wiesner test in cross-section of stems of S. vulgaris. Note: $\mathrm{mtx}$ - metaxylem; ptx - protoxylem; pf- pericyclic fibers; phl - phloem; lap - lignified axial parenchyma.
We observed that the anatomical structure of young stems of Sthruthantus vulgaris, after histochemical testing, presented highly lignified cells. The peripheral region is composed of epidermal cells, (pericyclic fibers). The bundles of phloematics cells were more prominent than other cells of the same region considering the lignification status.

We observed lignified cells (Figure 2) using the Wiesner test and identified differentiated protoxylem cells, demonstrating the existence of lignified secondary walls of protoxylem and no secondary wall deposition in the metaxylem (Figures 2A). We also observed secondary walls and metaxylem without secondary wall deposition (Figure 2B). The Wiesner test clearly showed the presence of lignin in pericyclic fibers (Figure 2C) (Lin \& Dence, 1992). The lignified axial parenchyma also exhibited cell wall thickening, as indicated by the arrows (Figure 2D).

After treatment with $\mathrm{NaOH} 1 \%$, (TAPPI standards - T-212 - 76 (Tappi, 1979)), the test showed color intensity reduction from reddish to pinkish in the phloem fiber caps (Figure 3A) and in the lignified axial parenchyma, and particularly in the protoxylem (Figures 3B and 3D). This difference can also be observed if compared to natural tissues (Figures 2 and 3) during fluorescence microscopy (Figures 4A, 4B and 4C, 4D, respectively). Great deposit of tannic substances was verified more internally in parenchyma cells of the pit, which cortical parenchyma and some phoematic bundles 
is consistent with the description reported by Salatino et al. (1993). These results corroborated the reports by Watanabe et al. (2004), who observed the presence of polyphenols in the wood of Eucalyptus through histochemical tests after treating samples with $\mathrm{NaOH} 1 \%$, which enabled the observation of the precise distribution of lignin in cell walls.

Fluorescence analysis of the cross-sections of young stems with and without treatment with $\mathrm{NaOH} 1 \%$ showed small distinction between lignin
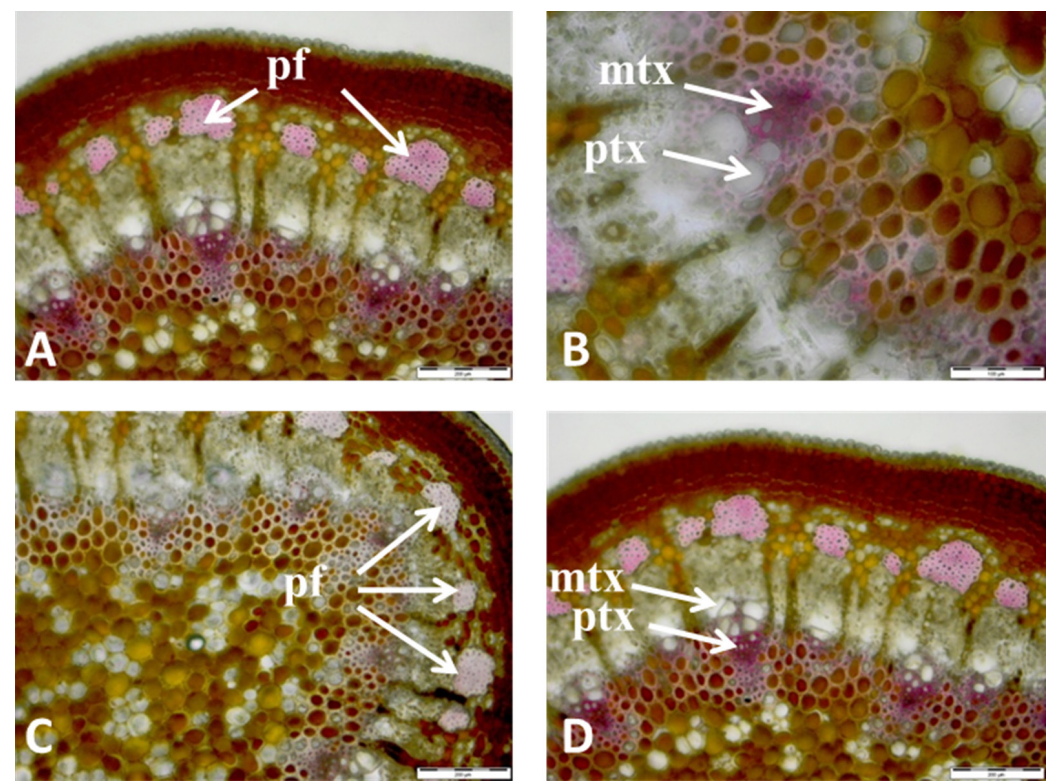

Figure 3. Cross section of stem of $S$. vulgaris treated with an aqueous $\mathrm{NaOH} 1 \%$ solution, and subsequently, using the Wiesner test. Note: pf - pericyclic fibers; mtx - metaxylem; ptx - protoxylem.
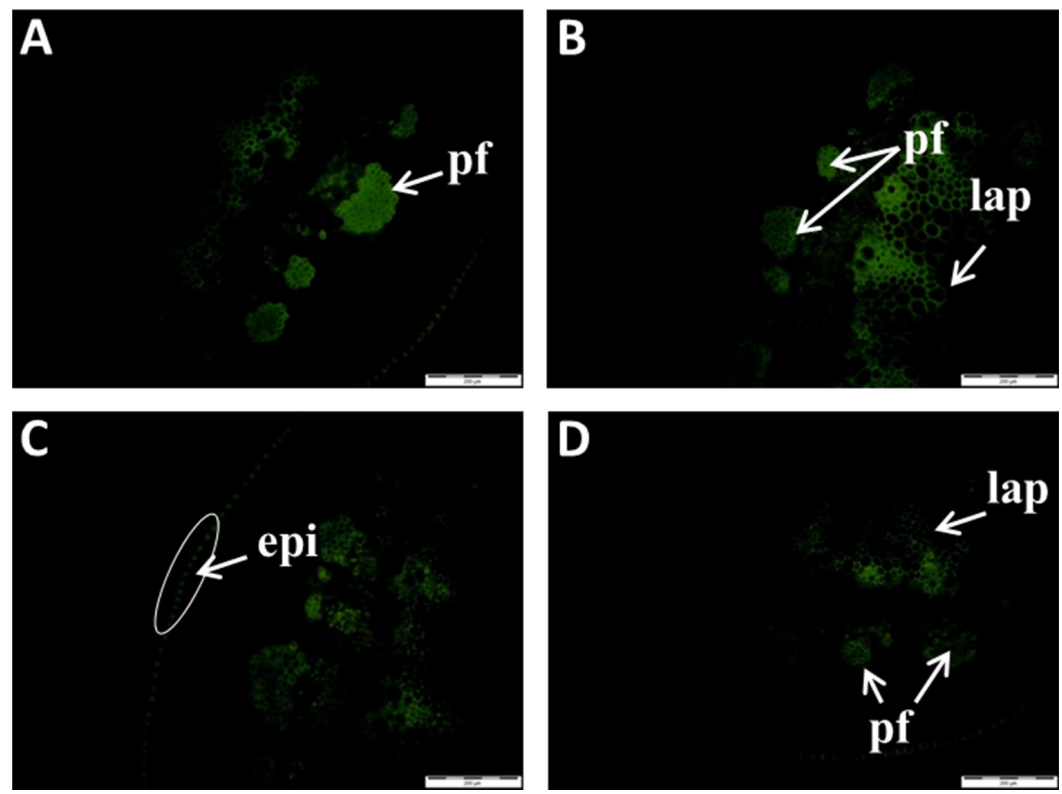

Figure 4. Photomicrographs showing auto fluorescence in cross-section of the non-treated stem (A and B) and stems treated with $\mathrm{NaOH}$ 1\% (C and D). Note: Epi-epidermis; pf - pericyclic fibers; epi-epidermis; lap - lignified axial parenchyma. 
molecular properties (Figure 4). The fluorescence technique also indicated presence of lignin, corroborating the results found previously. This analysis showed that pericyclic fibers are highly lignified compared to other tissues (Figure 4A). Axial parenchyma cells around the vascular bundles also exhibited presence of lignin confirmed by the Wiesner test and fluorescence microscopy. In this region, the protoxylem cells of the vascular bundle exhibited lignified secondary thickening (Figure 4B). Lignin was absent in epidermal cells (Figure 4C). Reduction of fluorescence intensity was observed after treatment with $\mathrm{NaOH} 1 \%$ (Figure 4C and 4D). This may be due to the presence of soluble lignin, which presents low molecular weight.

Natural cross sections of young stems were submitted to infrared microscopy of three distinct tissues (cortical parenchyma, pericyclic fibers and pith), as shown in Figures 5A, 5B and 5C, respectively.

The spectrum of the cortical parenchyma region did not present clear signs of lignin (Figure 5A), while the spectrum of the pericyclic fibers region (Figure 5B) showed the signals 1647, 1511, 1453, 1338 and $1244 \mathrm{~cm}^{-1}$,indicating presence of lignin despite the possibility of other phenol compound be present. The signals 1338 and $1244 \mathrm{~cm}^{-1}$ were assigned to the presence of syringyl and guaiacyl units, respectively. The first signal was slightly more intense than the second one (Obst, 1982).

Those assignments were performed according to the literature data (Lin \& Dence, 1992). The signal at $1733 \mathrm{~cm}^{-1}$ in the $\mathrm{B}$ spectrum may be attributed to the presence of ester carbonyl of polyoses (Lignin Carbohydrate complex- (L-C) complex); however, this could only be confirmed with the aid of other analytical methods.

The spectrum from the pith region showed complex signal profile, precluding any diagnosis (Figure 5C). The infrared spectra from xylem tissue were not registered; nevertheless, histochemical test and fluorescence confirmed the presence of lignin.

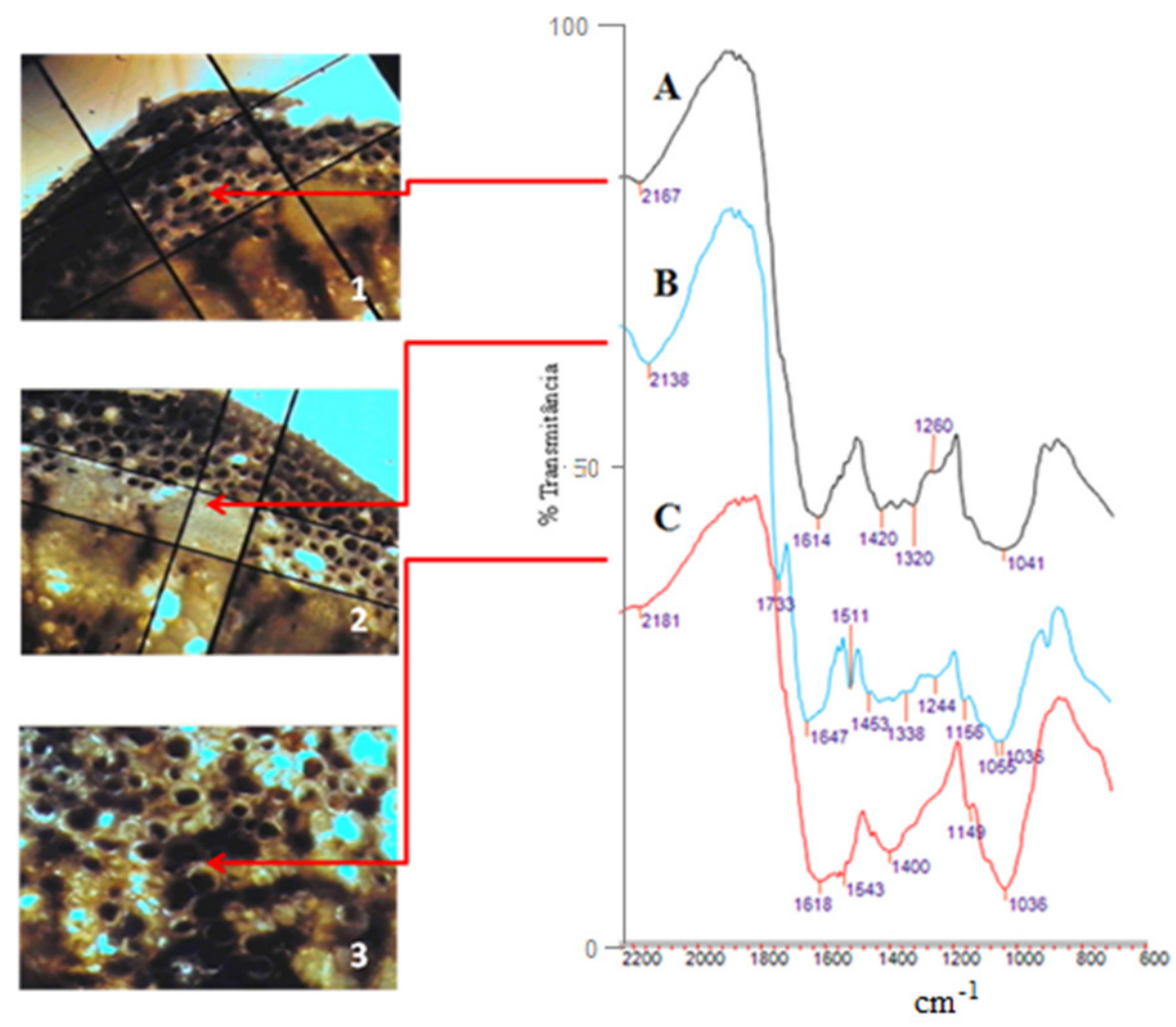

Figure 5. Infrared spectra of the natural cross-section of the following regions of the young stem: parenchyma (A), pericyclic fibers (B) and pith (C). 


\section{CONCLUSION}

Infrared microspectroscopy spectra recorded in situ showed highly lignified pericyclic fibers, with lignin of the Guaiacyl/Syringyl types. The high content of the syringyl unit in this region as well as the pericyclic fibers of phoematic bundle distribution ensure the high flexibility of young stems. By this method, we also verified that epidermis and parenchyma tissues did not contain lignin, at least under the conditions reported.

Fluorescence microscopy confirmed the results of infrared microspectroscopy, including the existence of phenolic compounds of low molecular mass before treatment with $\mathrm{NaOH} 1 \%$.

\section{ACKNOWLEDGEMENTS}

The authors are grateful to CAPES for the scholarship granted to the first author and to FAPERJ/CAPES for the equipment made available at the Wood Chemistry Laboratory, Forest Product Department, Federal Rural University of Rio de Janeiro (Universidade Federal Rural do Rio de Janeiro - UFRRJ).

\section{SUBMISSION STATUS}

Received: 09/25/2012

Accepted: 05/07/2013

Published: 06/30/2013

\section{CORRESPONDENCE TO}

\section{Gisely de Lima Oliveira}

Laboratório de Química da Madeira, Programa de Pós-graduação em Ciências Ambientais, Instituto de Florestas, Universidade Federal Rural do Rio de Janeiro - UFRGS, Rod. BR-465, Km 07, CEP 23890-000, Seropédica, RJ, Brasil e-mail: gyoliveira@gmail.com

\section{REFERENCES}

Aukema JE. Vectors, viscin, and Viscaceae: mistletoes as parasites, mutualists and resources. Frontiers in Ecology and the Environment 2003; 1(3): 212-219. http://dx.doi. org/10.1890/1540-9295(2003)001[0212:VVAVMA]2.0. $\mathrm{CO} ; 2$
Boerjan W, Ralph J, Baucher M. Lignin Biosynthesis. Annual Review of Plant Biology 2003; 54: 519-546. PMid:14503002. http://dx.doi.org/10.1146/annurev. arplant.54.031902.134938

Browning GL. Methods of wood chemistry. New York: Interscience Publishers; 1967. v. 2, p. 561-587.

Bukatsch F. Bemerkungenzur Doppelfärbung Astrablau-Safranin. Mikroskomos 1972; 61(8): 255.

Burton RA, Gidley M, Fincher GB. Heterogeneity in the chemistry, structure and function of plant cell walls. Nature Chemical biology 2010; 6: 724-732. PMid:20852610. http://dx.doi.org/10.1038/nchembio.439

De Micco V, Aronne G. Combined hostochemistry and autofluorescence for identifying lignin distribution in cell walls. Biotechnic \& Histochemistry 2007; 82(4-5): 209-216. PMid:18074267. http://dx.doi. org/10.1080/10520290701713981

Harris RW. Arboriculture: integrated management of landscape trees, shrubs and vines. New Jersey: PrenticeHall; 1992.

Higuchi T. Lignin structure and morphological distribution in plant cell walls. In: Kirk TK, Higuchi T, Chang H, editors. Lignin biodegradetion: microbiology, chemistry and potential applications. Boca Raton; 1980.

Kraus JE, Arduin M. Manual básico de métodos em morfologia vegetal. Editora Universidade Rural; 1997. 198 p

Lin SY, Dence CW. Methods in lignin chemistry. Berlim: Springer-Verlag; 1992. 568 p. http://dx.doi. org/10.1007/978-3-642-74065-7

Naumann A, González MN, Peddireddi UK, Polle A. Fourier transform infrared microscopy and imaging: Detection of fungi in wood. Fungal Genetics and Biology 2005; 42: 829-835. PMid:16098775. http:// dx.doi.org/10.1016/j.fgb.2005.06.003

Obst JR. Guaiacyl and Syringyl lignin composition in hardwood cell components. Holzforschung 1982; 36: 143-152. http://dx.doi. org/10.1515/hfsg.1982.36.3.143

Raven PH, Evert RF, Eichhorn SE. Biologia Vegetal. 7th ed. Rio de Janeiro: Editora Guanabara Koogan S. A.; 2007.

Rotta E. Erva-de-passarinho (Loranthaceae) na arborização urbana: Passeio Público de Curitiba, um estudo de caso [tese]. Curitiba: Setor de Ciências Agrárias, Universidade Federal do Paraná; 2001.

Salatino A, Kraus JE, Salatino MLF. Contents of Tannins and their histological localization in Young and adult parts of Struthanthus vulgaris Mart. (Loranthaceae). 
Annals of Botany 1993; 72: 409-414. http://dx.doi. org/10.1006/anbo.1993.1126

Technical Association of the Pulp and Paper Industry - TAPPI. TAPPI test methods T 212 os-76: one per cent sodium hydroxide solubility of wood and pulp. Atlanta: Tappi Technology Park; 1979.

Tainter FH. What does mistletoes have to do with Christmas? Feature Story. St. Paul: American Phytopathological Society; 2002. [cited 2005 jul. 20]. Available form: http://www.apsnet.org/online/feature/ mistletoes.
Tattar TA. Diseases of Shade Trees. New York: Academic; 1978.

Umezawa T. The cinnamate/mnolignol pathway. Phytochemistry Reviews 2010; 9: 1-17. http://dx.doi. org/10.1007/s11101-009-9155-3

Watanabe Y, Kojima Y, Ona T, Asada T, Sano Y, Fukazawa $\mathrm{K}$ et al. Histochemical study on heterogeneity of lignin in Eucalyptus species II. The distribution of lignins and polyphenols in the walls of various cell types. IAWA Journal 2004; 25(3): 283-295. http://dx.doi. org/10.1163/22941932-90000366 